Plant Protection and Quarantine 2017. Issue 63.

UDC 575+577.1 : 633.1

\author{
N.A. KOZUB, PhD in biology \\ I.A. SOZINOV, senior researcher \\ G.Ya. BIDNYK, senior specialist \\ N.A. DEMIANOVA, senior specialist \\ O.I. SOZINOVA, senior specialist \\ A.V. KARELOV, PhD in biology \\ Institute of Plant Protection, National Academy of Agrarian Sciences of \\ Ukraine
}

Ya.B. BLUME, doctor of biological sciences

A.A. SOZINOV, doctor of agricultural sciences

Institute of Food Biotechnology and Genomics, National Academy of

Sciences of Ukraine

\title{
DEVELOPMENT OF COMMON WHEAT LINES WITH THE 1BL/1RS TRANSLOCATION LINKED WITH THE ALLELE Glu-B1al
}

A number of $F_{6}$ winter common wheat lines that carry the wheat-rye $1 B L / 1 R S$ translocation of the Kavkaz type with respective resistance genes linked with high bread-making quality allele Glu-B1al have been developed via marker selection among $F_{2}$ plants from the cross B16 $\times$ Odesskaya krasnokolosya. The SDS-sedimentation value in these lines proved to be in most cases similar to that of the cultivar Bezostaya 1. The lines may be used as a source of the 1BL/1RS translocation linked with the high-quality allele Glu-B1al, which compensates for the negative effect of this translocation on bread-making quality.

common wheat, wheat-rye translocation $1 \mathrm{BL} / 1 \mathrm{RS}$, disease resistance genes, bread-making quality, SDS sedimentation

The wheat-rye $1 \mathrm{BL} / 1 \mathrm{RS}$ translocation from the rye Petkus (the translocation between the short arm of rye chromosome $1 \mathrm{R}$ and the long arm of wheat chromosome 1B) as in the cultivar Kavkaz is the most widespread alien translocation among commercial common wheat cultivars [20]. For example about $64 \%$ of cultivars from northern China carry the 1BL/1RS translocation [12]. Its frequency comprised 36\% among cultivars grown in Argentina [17], 13\% in the sample of cultivars of the United Kingdom, 27\% in the pooled samples of German and Dutch cultivars, 23\% in Australian cultivars (the frequencies were calculated on the basis of genotypes presented in [26]). According to our data, this translocation is found in $14 \%$ of 
Ukrainian winter common wheat cultivars [10]. These are predominantly cultivars of the Central Forest-Steppe zone. The proportion of such cultivars developed in the last two decades amounts 38\% [10]. Moreover, this translocation was identified in $50 \%$ of promising breeding lines and new cultivars of the Myronivka Remeslo Institute of Wheat of the National Academy of Agrarian Sciences of Ukraine (NAAS) (MIW), developed in 2012-2015 [1]. The high frequency of occurrence of this translocation may be due to the presence of disease resistance genes [14], as well as genes for more intense development of the root system [11].

The 1BL/1RS translocation carries a number of disease resistance genes: Pm 8 for resistance to powdery mildew caused by Erysiphe graminis (DC), the $S r 31$ gene for resistance to stem rust caused by Puccinia graminis Pers. f. sp. tritici Erikss. et Henn., the gene Lr 26 for resistance to leaf rust caused by Puccinia recondita f. sp. tritici Rob ex Desm., and the $Y r 9$ gene for resistance to stripe rust caused by Puccinia striiformis West. [14]. Among these genes the most important is $S r 31$, which is effective against all stem rust races except for Ug99 [19]. In many studies, the positive effect of the presence of the 1BL/1RS translocation on agronomic performance was demonstrated $[15,24,25]$. However, it is common knowledge that this translocation impairs bread-making quality [6]. This adverse effect can be compensated by the presence of certain alleles at the Glu-1 loci encoding high molecular-weight glutenin subunits, which are directly involved in determination of bread-making quality of grain [18]. The Glu-1 loci are located on the long arms of homoeologous group 1 chromosome at a distance of $10 \%$ of recombination from the centromere [18]. Virtually all Ukrainian cultivars with the $1 \mathrm{BL} / 1 \mathrm{RS}$ translocation carry it in combination with the allele $G l u-B 1 c$ [10], which has a moderate effect on bread-making quality, according to Payne et al. [28]. The allele that greatly improves bread-making quality is Glu-Blal. The first Ukrainian extra-strong cultivars with this allele were Panna and Leleka developed on the basis of the cultivar Odesskaya krasnokolosya [4]. A special feature of carriers of this allele is high physical properties of dough even at a substantial level of grain damage by sunn pest Eurygaster integriceps Put. According to the data of Poperelya and Blagodarova [4], such wheats retain high bread-making properties of flour (bread volume) even at the $9 \%$ level of damage by E. integriceps. Sunn pest and other corn bugs in the course of feeding inject saliva gland secrets into seeds. These secrets contain enzymes, in particular proteinases hydrolyzing the major wheat endosperm proteins, gliadins and glutenins [5, 9]. It is believed that damage of $2-3 \%$ of seeds deteriorates bread-making quality, although $3-5 \%$ is accepted as the critical threshold [9]. Investigation of corn bug-damaged seeds has demonstrated that its proteases cause degradation of polymeric glutenin [9]. Gluten from extra-strong wheat (the cultivar Glenlea with the allele Glu$B$ lal) proved to be less sensitive to the action of proteases [23], evidently 
due to its special features: a relatively high content of insoluble glutenin and a low content of soluble glutenin [22].

The objective of our investigation was development of common wheat lines carrying the wheat-rye $1 \mathrm{BL} / 1 \mathrm{RS}$ translocation coupled with the allele Glu-Blal and analysis of their bread-making quality.

Materials and methods. Winter common wheat $\mathrm{F}_{2}$ plants from the reciprocal cross B16 $\times$ Odesskaya krasnokolosaya (2088 plants) served as the initial material for developing lines. The line B16 carries the wheat-rye $1 \mathrm{BL} / 1 \mathrm{RS}$ translocation coupled with the allele Glu-B1e, and the cultivar Odesskaya krasnokolosya has the allele Glu-B1al. The allele Gli-B1l controlling synthesis of specific secalins (Gld 1B3) serves as a marker of the $1 \mathrm{BL} / 1 \mathrm{RS}$ translocation of the Kavkaz type $[6,16]$. To determine the genotype of $\mathrm{F}_{2}$ plants at marker loci, 5-15 single seeds were analyzed by electrophoresis of storage proteins. Acid polyacrylamide gel electrophoresis of gliadins was performed by the procedure [2] with modifications described in [27]. Electrophoresis of high-molecular-weight glutenin subunits was carried out by the procedure of Laemmli [13] on $10 \%$ gels. The offspring of selected $\mathrm{F}_{2}$ plants with desirable combinations of alleles ( $\mathrm{Gli}-\mathrm{B} 1 \mathrm{l}$ associated with $G l u-B 1 a l)$ were resown on the experimental plot to obtain $\mathrm{F}_{6}$ lines.

Five $\mathrm{F}_{6}$ lines $(622,380-1,380-3,616-3$, and 616-5) were grown on the experimental plot (Hatne, Kyiv region) in 2008-2009 with 3-6 replicates (1.2-m plots) along with the standards, Bezostaya 1, Panna (the carrier of the allele Glu-Blal), and B16 (the parental form with 1BL/1RS) and in 2014-2015 with 4 replicates and with the standards Bezostaya 1 and Panna as well as both the parental forms (Odesskaya krasnokolosya and B16) in a completely randomized block design (0.5-m plots). Values of the sodium dodecyl sulfate (SDS) test [7], the quality test based on sedimentation of whole meals, of the lines and the standards were assessed in the Plant Breeding and Genetics Institute - National Center of Seed and Cultivar Investigation (PBGI) by the SDS30 sedimentation procedure [3] as sedimentation volume $(\mathrm{ml})$. In the case of samples harvested in 2009 there were three biochemical replicates.

The significance of differences was estimated using Student's test. To determine the effect of the year of growing on the SDS sedimentation value, analysis of variance was used.

Results and discussion. Among more than $2000 \mathrm{~F}_{2}$ plants from the reciprocal cross B16 $\times$ Odesskaya krasnokolosaya, analysis of genotypes at the marker loci Gli-B1 and Glu-B1 revealed 2 homozygotes with the allele Gli$B 11$ (the presence of the $1 \mathrm{BL} / 1 \mathrm{RS}$ translocation) in combination with the high-quality allele $\mathrm{Glu}$-Blal and about 40 plants that were homozygous for the presence of the wheat-rye translocation and heterozygous at the locus $G l u-B 1$. The low frequency of plants with the desired combination of alleles is evidently due to the relatively tight linkage of $G l u-B 1$ and the rye arm 1RS 
within the translocation (about $10 \%$ of recombination) as well as selection against gametes with $1 \mathrm{BL} / 1 \mathrm{RS}$ in heterozygotes for the translocation [2, 21], which causes the decline in the proportion of homozygotes for the translocation. Offspring of the selected $\mathrm{F}_{2}$ plants were grown and the best forms with respect to habitus and yield were resown to obtain lines. Among the offspring of plants heterozygous at the locus $G l u-B 1$, homozygotes with the genotype Gli-B1l Glu-B1al were selected using electrophoresis of high-molecular-weight glutenin subunits. As a result, we developed a number of $F_{6}$ lines combining advantages of the presence of the wheat-rye translocation (namely the presence of respective disease resistance genes) and the high grain quality allele Glu-Blal.

Five $\mathrm{F}_{6}$ lines with the genotype Gli-B1l Glu-B1al, 622, 616-3, 616-5, $380-1$, and 380-3, were assessed for the level of bread-making quality using the SDS30 test [3], which is based on sedimentation behavior of whole meals and flours in SDS solution [7]. For comparison, quality indices of the standards (the cultivars Bezostaya 1 and Panna) and the parental forms (Odesskaya krasnokolosaya and B16) grown in the same experiments were also analyzed. The cultivar Bezostaya 1 was chosen as it carries the most common high-molecular-weight glutenin subunit alleles, Glu-A1b, Glu-B1c, $G l u-D 1 d$, and shows good bread-making quality. The cultivar Panna, which carries the high-quality alleles Glu-Blal and Glu-D1d, was developed on the basis of the cultivar Odesskaya krasnokolosaya [4]. The characteristics of the lines and the cultivars with respect to the high-molecular-weight glutenin subunit loci and the presence of the 1BL/1RS translocation of the Kavkaz type, which primarily influence bread-making quality, are presented in Table 1. Some of the lines with the wheat-rye translocation coupled with the high-quality allele $G l u-B 1 a l$ (622, 380-1, and 380-3) also carry another high-quality allele, Glu-D1d [28].

SDS sedimentation volume was influenced by growth conditions $(\mathrm{F}=$ $10.54, \mathrm{P}<0.01)$. Under conditions of 2015 , values of SDS sedimentation in the lines and the cultivars were in most cases higher than those in 2009 (Table 2). The lines with the wheat-rye 1BL/1RS translocation associated with the allele $G l u$-Blal showed intermediate SDS sedimentation volumes as compared to the parental forms, B16 and Odesskaya krasnokolosaya.

SDS sedimentation volumes in the lines 622, 380-1, and 380-3 with the wheat-rye translocation and the allele Glu-Blal were not lower than that in the cultivar Bezostaya 1 in both years of investigation, and 380-3 even showed the significantly higher value in 2009 (Table 2). However, in the case of the experiment in 2009, the lines 616-3 i 616-5 showed lower SDS sedimentation volumes in comparison with that in Bezostaya 1. A special feature of these lines is the presence of the allele Glu-D1a, which is associated with a lower level of bread-making quality as compared to the allele Glu-D1d [28]. Thus the negative effect of the wheat-rye 1BL/1RS translo- 
1. The characteristics of common wheat cultivars and lines with respect to the high-molecular-weight glutenin subunit loci and the presence of the $1 B L / 1 R S$ translocation of the Kavkaz type

\begin{tabular}{|l|c|c|c|c|}
\hline \multicolumn{1}{|c|}{ Line, cultivar } & Glu-A1 & Glu-B1 & Glu-D1 & $\begin{array}{c}\text { 1BL/1RS } \\
\text { (Gli-B1l) }\end{array}$ \\
\hline B16 & $c$ & $e$ & $a$ & + \\
\hline 622 & $b$ & $a l$ & $d$ & + \\
\hline $616-3$ & $b$ & $a l$ & $a$ & + \\
\hline $616-5$ & $b$ & $a l$ & $a$ & + \\
\hline $380-1$ & $c$ & $a l$ & $d$ & + \\
\hline $380-3$ & $b$ & $a l$ & $d$ & + \\
\hline Bezostaya 1 & $b$ & $c$ & $d$ & - \\
\hline Odesskaya krasnokolosaya & $b$ & $a l$ & $d$ & - \\
\hline Panna & $b$ & $a l$ & $d$ & - \\
\hline
\end{tabular}

cation can be compensated by the allele $G l u$-Blal, especially in the presence of another high-quality allele, Glu-D1d. It should be noted that the allele Glu-D1d is encountered in $90 \%$ of Ukrainian common wheat cultivars [10].

In the Ukrainian winter common wheat gene pool, carriers of the wheat-rye 1BL/1RS translocation with respective disease resistance genes, including the currently effective genes $\operatorname{Yr} 9$ and $\operatorname{Sr} 31$, are frequent among the

2 SDS sedimentation volumes in the common wheat lines with the wheat-rye 1BL/1RS translocation and the allele Glu-B1al, as well as in the standards grown in different years

\begin{tabular}{|c|c|c|}
\hline \multirow{2}{*}{ Line, cultivar } & \multicolumn{2}{|c|}{ SDS sedimentation volume, $\mathrm{ml}$} \\
\hline & 2009 & 2015 \\
\hline B16 & $30.0 \pm 0.4$ & $37.3 \pm 1.3$ \\
\hline 622 & $49.7 \pm 0.2$ & $53.3 \pm 1.9$ \\
\hline $616-3$ & $43.2 \pm 0.7^{* * *}$ & $54.5 \pm 1.7$ \\
\hline $616-5$ & $48.1 \pm 0.7^{*}$ & $55.5 \pm 3.8$ \\
\hline $380-1$ & $51.0 \pm 1.0$ & $56.0 \pm 1.6$ \\
\hline $380-3$ & $53.2 \pm 0.7^{* *}$ & $57.0 \pm 2.9$ \\
\hline Bezostaya 1 & $50.8 \pm 0.8$ & $58.5 \pm 2.2$ \\
\hline Odesskaya krasnokolosaya & - & $66.5 \pm 1.5$ \\
\hline Panna & $70.8 \pm 2.6$ & $72.5 \pm 2.7$ \\
\hline \multicolumn{3}{|c|}{$\begin{array}{l}\text { Notes: } *, * *, * * \text { Differences from the value in the cultivar Bezostaya } 1 \text { are significant } \\
\text { at } \mathrm{P}<0.05, \mathrm{P}<0.01, \mathrm{P}<0.001 \text {, respectively }\end{array}$} \\
\hline
\end{tabular}


Forest Steppe cultivars developed in MIW, the Institute of Plant Physiology and Genetics of the National Academy of Sciences of Ukraine, the Bila Tserkva Experimental Station of the Institute of Bioenergy Crops and Sugar Beet of NAAS, and the National Science Centre "Institute of Agriculture NAAS Ukraine" [10]. At the same time this translocation is rare among the Steppe cultivars developed in PBGI evidently due to stringent requirements on bread-making quality of grain in the breeding process. In its turn, the allele Glu-Blal associated with improved dough strength is currently found only among the Steppe cultivars (of PBGI breeding) with a frequency of $10 \%$ [10]. The coupling of the wheat-rye $1 \mathrm{BL} / 1 \mathrm{RS}$ translocation and the high-quality allele $G l u-B 1 a l$ would permit to fully exploit the benefits of this translocation - the presence of disease resistance genes and other important genes without the severe deterioration in bread making quality. The lines with the combination of the 1BL/1RS translocation and the allele Glu-Blal have been passed over to breeders as initial material.

\section{CONCLUSIONS}

We have developed a number of $\mathrm{F}_{6}$ lines combining benefits of the presence of the wheat-rye $1 \mathrm{BL} / 1 \mathrm{RS}$ translocation of the Kavkaz type (the presence of respective disease resistance genes) and the allele Glu-Blal associated with improved dough strength. The SDS sedimentation volume in these lines is similar to that of the cultivar Bezostaya 1, which shows good bread-making quality. These lines can be a source of the 1BL/1RS translocation linked with the high-quality allele Glu-Blal, which compensates for the negative effect of this translocation on bread-making quality.

\section{REFERENCES}

1. Ідентифікація вихідного матеріалу пшениці озимої миронівської селекції за електрофоретичними спектрами запасних білків / İ.O. Созінов, Н.О. Козуб, В.В. Кириленко та ін. // Агробіологія. - 2015. № 2. - С. 46-53.

2. Козуб Н.А. Особенность расщепления по аллелям глиадинкодирующего локуса $G l i-B 1$ у гибридов озимой мягкой пшеницы / Н.А. Козуб, И.А. Созинов // Цитология и генетика. - 2000. - Т. 34, № 2. - C. 69-76. (Kozub, N.A., and I.A. Sozinov, Distorted segregation at the gliadin locus $G l i-B 1$ in winter common wheat hybrids. Tsitol. Genet., 2000, vol. 34, no. 2, pp. 69-76.)

3. Наукове обгрунтування розробки нових методів оцінки хлібопекарської якості борошна пшениці / О.Іे. Рибалка, М.В. Червоніс, І̇.Г. Топораш, та ін. // Хранение и переработка зерна. -2006 . - № 1 (79). - C. 43-48.

4. Попереля Ф.О. Генетика якості зерна перших генотипів надсильної пшениці України / Ф.О. Попереля, О.М. Благодарова // Цитология и генетика. - 2000. - Т. 32, № 6. - C. 11-19. (F.O. Poperelya, 
O.M. Blagodarova, Genetics of grain quality of first Ukrainian genotypes of superstrong wheat // Tsitol. Genet. - 1998. - Vol. 32, N. 6. - P. 11-19).

5. Свойства нативных и рекомбинантных протеиназ слюнных желез клопа вредная черепашка (Eurygaster integriceps Put.), гидролизующих клейковину пшеницы / Ал.В. Конарев, В.В. Долгих, И.В. Сендерский // Вестник защиты растений. - 2014. - N 2. - С. 3-16.

6. Созинов A.A. Полиморфизм белков и его значение в генетике и селекции / А.А. Созинов. - М.: Наука, 1985. - 272 .

7. Axford D.W.E. Note on the sodium dodecyl sulfate test of breadmaking quality: Comparison with Pelshenke and Zeleny tests / D.W.E. Axford, E.E. McDermott, D.G. Redman // Cereal Chem. - 1979. - Vol. 6, N 6. - P. 82-584.

8. Changes in the composition and size distribution of endosperm proteins from bug-damaged wheats / D. Sivri, I.L. Batey, D.J. Skylas et al. // Crop and Pasture Science. - 2004. - Vol 55, No. 4. - P. 477-483.

9. Critchley B.R. Literature review of sunn pest Eurygaster integriceps Put. (Hemiptera, Scutelleridae) / B.R. Critchley // Crop Protection. 1998. - Vol. 7, No. 4. - P. 271-287.

10. Diversity of Ukrainian winter common wheat varieties with respect to storage protein loci and molecular markers for disease resistance genes / N.A Kozub, I.A. Sozinov, A.V. Karelov et al. // Cytol. Genet. - 2017. Vol. 51, № 2. - P. 53-67.

11. Ehdale B. Root biomass, water-use efficiency, and performance of wheat rye translocations of chromosomes 1 and 2 in spring bread wheat 'Pavon' / B. Ehdale, R.W. Whitkus, J.G. Waines // Crop Science. 2003. - 43. - P. 710-717.

12. Investigation of genetic diversity and population structure of common wheat cultivars in northern China using DArT markers / L.Y. Zhang, D.C. Liu, X.L. Guo et al. // BMC Genetics. - 2011. - Vol. 12. - P. 42. Режим доступу: http://www.biomedcentral.com/1471-2156/12/42.

13. Laemmli U.K. Cleavage of structural proteins during the assembly of the head of bacteriophage T4 / U.K. Laemmli // Nature. - 1970. Vol. 227, N 5259. - P. 680-685.

14. Mac Gene, Gene Symbols, Gene Classes and References [Електронний ресурс]. - 2013. - Режим доступу: http://www.shigen.nig.ac.jp/ wheat/komugi/genes/macgene/2013/ GeneSymbol.pdf.

15. Mapping a region within the 1RS.1BL translocation in common wheat affecting grain yield and canopy water status / T. Howell, I. Hale, L. Jankuloski, M. Bonafede // Theor. Appl. Genet. - 2014. - Vol. 127. P. 2695-2709.

16. Metakovsky E.V. Gliadin allele identification in common wheat. II Catalogue of gliadin alleles in common wheat / E.V. Metakovsky // J. Genet. Breed. - 1991. - Vol. 45. - P. 325-344. 
17. Lerner S.E. Quality and endosperm storage protein variation in Argentinian grown bread wheat. I Allelic diversity and discrimination between cultivars / S.E. Lerner, M.A. Kolman, W.J. Rogers // Journal of Cereal Science. - 2009. - Vol. 49. - P. 337-345.

18. Payne P.I. Genetics of wheat storage proteins and the effect of allelic variation on bread-making quality / P.I. Payne // Ann. Rev. Plant Physiol. - 1987. - Vol. 38. - P. 141-153.

19. Pretorius Z.A. Detection of virulence to wheat stem rust resistance gene Sr31 in Puccinia graminis f. sp. tritici in Uganda / Z.A. Pretorius // Plant Disease. - 2000. - Vol. 84, N 2. - P. 203.

20. Rabinovich S.V. Importance of wheat-rye translocations for breeding modern cultivars of Triticum aestivum L. / S.V. Rabinovich // Euphytica. 1998. - Vol. 100. - P. 323-340.

21. Rayburn A.L. Inheritance of a $1 \mathrm{BL} / 1 \mathrm{RS}$ wheat-rye translocated chromosome in wheat / A.L. Rayburn, D.W. Mornhinweg // Crop Sci. 1988. - Vol. 28, N 4 - P. 709-711.

22. Sapirstein H.D. Intercultivar variation in the quantity of monomeric proteins, soluble and insoluble glutenin, and residue protein in wheat flour and relationships to breadmaking quality / H.D. Sapirstein, B.X. Fu // Cereal Chem. - 1998. - Vol. 75, N 4. - P. 500-507.

23. Sivri D. The effects of wheat-bug (Eurygaster integriceps) protease on the spectral characteristics (Vis/NIR) of gluten proteins / D. Sivri, H. Koksel, P. Williams // AACC 2000 Annual Meeting, November 5-9, 2000 Kansas City, Missouri. - P. 157. - Режим доступу: http://www.aaccnet. org/meetings/Documents/Pre2009Abstracts/2000Abstracts/a00ma157.htm

24. The $1 B L / 1 R S$ translocation: agronomic performance of $\mathrm{F}_{3}$-derived line from a winter wheat cross / B. Moreno-Sevilla, P.S. Baenzinger, C.J. Peterson et al. // Crop. Sci. - 1995. - Vol. 35, № 4. - P. 1051-1055.

25. The effect of chromosome 1B/1R translocation on the yield potential of certain spring wheats (Triticum aestivum L.) / R.L. Villareal, S. Rajaram, A. MuJeeb-Kazi, E. Del-Toro // Plant Breed. - 1991. - Vol. 106. P. $77-81$.

26. The gluten composition of wheat varieties and genotypes / C.W. Wrigley, F. Bakes, C.R. Cavagh, W. Bushuk. - 2006. - Режим доступу: http://www.aaccnet.org/initiatives/definitions/Pages/gliadin.aspx

27. Variation at storage protein loci in winter common wheat cultivars of the Central Forest-Steppe of Ukraine / N.A. Kozub, I.A. Sozinov, T.A. Sobko [et al.] // Цитология и генетика. - 2009. - T. 43, № 1. C. 69-77 (Kozub, N.A., Sozinov, I.A., Sobko, T.A., Kolyuchii, V.T., Kuptsov, S.V., Sozinov, A.A., Variation at storage protein loci in winter common wheat cultivars of the Central Forest-Steppe of Ukraine, Cytol. Genet., 2009, vol. 43, no. 1, pp. 55-62).

28. Wheat storage proteins: their genetics and their potential for manipu- 
lation by plant breeding / P.I. Payne, L.M. Holt, E.A. Jackson, C.N. Law // Phil. Trans. Roy. Soc. (London). - 1984. - Vol. 304. - P. 359-371.

Козуб Н.О., Созінов І.О., Бідник Г.Я., Дем'янова Н.О., Созінова О.І., Карелов А.В., Блюм Я.Б., Созінов О.О. Створення ліній пшениці м'якої з транслокацією 1BL/1RS, зчепленою з алелем високої якості Glu-Blal

За допомогою маркерного відбору серед рослин $F_{2}$ від схрещення Б16 × Одеська червоноколоса створено низку ліній $F_{6}$ пшенищі м'якої озимої, що мають пшенично-жситню транслокацію 1BL/1RS типу Кавказ з відповідними генами стійкості, зчеплену з алелем надвисокої якості зерна Glu-Blal. Визначено, що показник SDS-седиментації у цих ліній, переважно, знаходиться на рівні величини у сорту Безоста 1. Створені лінії можуть бути джерелом $1 B L / 1 R S$ транслокації, зчепленої з алелем високої якості Glu-Blal, який компенсує негативний ефект даної транслокації на хлібопекарну якість.

Козуб Н.А., Созинов И.А., Биднык А.Я., Демьянова Н.О., Созинова О.И., Карелов А.В., Блюм Я.Б., Созинов А.А. Создание линий пшеницы мягкой с транслокацией $1 \mathrm{BL} / \mathrm{RS}$, сцепленной с аллелем високого качества Glu-B1al

C помошью маркерного отбора среди растений $F_{2}$ от скрещивания Б16 × Одесская красноколосая создан ряд линий $F_{6}$ пшеницы мягкой озимой, имеющих пшенично-ржаную транслокацию $1 B L / 1 R S$ типа Кавказ с соответствующими генами устойчивости, сцепленную с аллелем высокого качества зерна Glu-Blal. Показатель SDS-седиментации у этих линий, преимущественно, находится на уровне величины у сорта Безостая 1. Созданные линии могут быть источником 1BL/1RS транслокации, сиепленной с аллелем високого качества Glu-Blal, который компенсирует отрицательный эффект данной транслокации на хлебопекарное качество. 